\title{
Koninkryksetiek as hoopgewende getuienis in sekulêre ruimtes
}

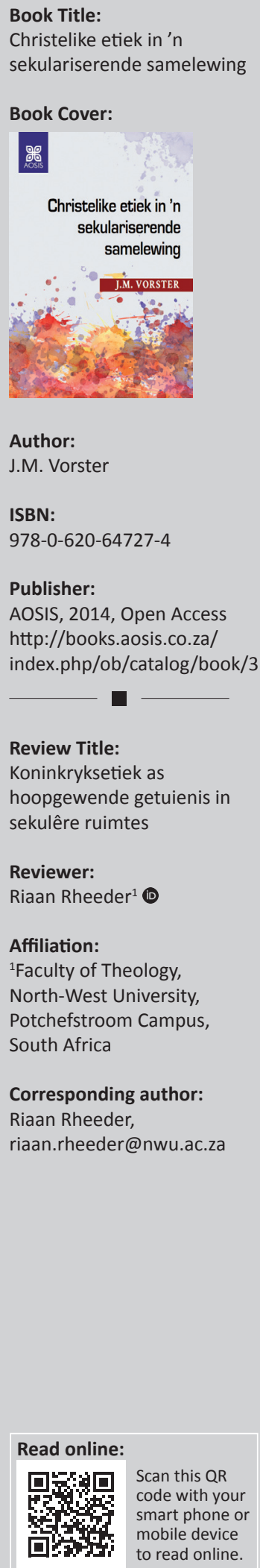

Koos (J.M.) Vorster se boek Christelike etiek in 'n sekulariserende samelewing (2014), bevestig net weer my standpunt dat hy as een van die mees uitstaande teoloë van die Gereformeerde Kerke van Suid-Afrika (GKSA) gereken kan word. Na die voortydige afsterwe van een van ons kollegas aan die Fakulteit Teologie van die NWU (prof. F.W. de Wet) is my oordeel dat ek laasgenoemde bewering eerder nou as op 'n latere tydstip wil maak.

Vorster het die vermoë om ingewikkelde begrippe en konsepte op 'n eenvoudige en verstaanbare wyse en in duidelike taal weer te gee sonder dat enige afbreuk aan deeglikheid en wetenskaplikheid gemaak word, of in oppervlakkigheid verval word. Sy verduideliking van die konsep sekularisme in hoofstuk 1 is ' $n$ voorbeeld hiervan. Die boek is vanuit ' $n$ gebalanseerde reformatoriese perspektief geskryf en die tema van sekularisasie is besonder aktueel vir die moderne wêreld. Die boek is dus uiters relevant - nie net vir die akademiese omgewing en studente nie, maar ook vir lidmate en ander belangstellendes. Dit sou egter baie waardevol wees indien die boek in Engels vertaal kon word om sodoende vir lesers dwarsoor die wêreld meer toeganklik te wees.

In hoofstuk 1 (bl. 1-21) word die invloed op die christelike geloof asook christelike reaksies op sekularisme in hooftrekke bespreek. Vorster tipeer sekularisasie onder andere as die agteruitgang van godsdiens en die verlies aan invloed van die kerk en die christelike moraal in Westerse samelewings (bl. 2). Hy stel die navorsingsprobleem soos volg: 'Kan christelike moraliteit nog effektief die lewens van moderne mense beïnvloed en 'n christelike lewenswyse kweek?' Vorster se sentraal-teoretiese argument is dat christelike etiek ' $n$ belangrike rolspeler in die moderne sekulariserende Westerse samelewings kan wees indien die dissipline op geloofwaardige, goedgevestigde en gedefinieerde metateoretiese grondslae gefundeer word. Die res van die boek fokus op die uitbou van hierdie teoretiese stelling.

In hoofstuk 2 (bl. 22-35) gee Vorster aandag aan die konsep van postsekularisme wat beweer dat daar 'n omkeer in die proses van sekularisasie te sien is. Dit beteken dat die kerk deur 'n nuwe reformasie beweeg. Hy erken die konsep postsekularisme, maar ontken dat dit 'n teologiese en kerklike reformasie beteken. Volgens hom gun hierdie verskynsel hoogstens weer ruimte aan die mistieke en die metafisiese wat ook ruimte vir die aanvaarding en belewing van Christelike etiek in 'n sekulariserende samelewing insluit (bl. 35-36).

Volgens Vorster berus 'n geloofwaardige christelike etiek op die totale godsopenbaring wat die natuurreg (natural law) (Rom 2:14-15), die geskrewe en vleesgeworde Woord insluit (Joh 1:14). In hoofstuk 3 (bl. 37-59) gee Vorster in diepte aandag aan die konsep van die natuurreg en kom tot die volgende gevolgtrekking:

God se openbaring in die skepping en regering van alle dinge is die grond van natuurreg wat die mens deur sy rede kan ontsluit. So 'n rasionele ontsluiting van die natuurreg bring mee dat morele norme gevind kan word wat vir alle mense kan geld. Christelike etiek kan ook hieruit put. (bl. 58)

Na die erkenning van die natuurreg word in hoofstuk 4 (bl. 60-82) aangevoer dat etiese kennis duideliker en suiwerder gemyn word uit die openbaring in die geskrewe Woord, die Skrif. Daarom moet die christelike etikus ook in die tyd van sekularisme bly vra: 'Wat sê die Skrif?' Sonder die Skrif kan etiek nie geloofwaardig wees nie. Die geskrewe Woord vereis 'n bepaalde benadering ten opsigte van interpretasie en toepassing. Die Skrif moet as ' $n$ eenheid benader word wat 'n deurlopende ontvouende tematiese openbaring bied (teenoor die historiese kritiese en biblistiese benaderings). Hierdie besondere tema wat soos 'n goue draad deur die Skrif loop, is die koninkryk van God wat 'n hoopgewende en transformerende etiek bied.

How to cite this book review: Rheeder, R., 2016, 'Koninkryksetiek as hoopgewende getuienis in sekulêre ruimtes, In die Skriflig 50(1), a2106. http://dx.doi.org/10.4102/ids.v50i1.2106

Copyright: @ 2016. The Authors. Licensee: AOSIS. This work is licensed under the Creative Commons Attribution License. 
In hoofstuk 5 (bl. 83-101) redeneer Vorster dat etiek wat uit die boek van die natuur (natuurreg) en die geskrewe Woord afgelei word uiteindelik getoets moet word. Hierdie toets is die mensgeworde Woord, Jesus Christus. Christelike etiek is 'n koninkryksetiek waarop Christus die 'vetoreg' het en wat dus christologies beoordeel moet word.

In hoofstuk 6 (bl. 102-135) behandel Vorster die Tien Gebooie as koninkryksetiek en bied 'n eie, unieke en besondere interpretasie daaraan. Die waarde van die hoofstuk word in die volgende hermeneutiese riglyn gevind:

In die hermeneutiek van die etiek gaan die gelowige begin by die Tien Gebooie met die vraag: Bied die Tien Gebooie in sy sinekdogetiese karakter lig en leiding ten opsigte van 'n bepaalde etiese probleem? Indien nie, moet die lig en leiding gesoek word in die geskrewe Woord. Bied die Skrif enige lig en leiding vir die bepaalde etiese probleem? Indien dit nie duidelik is nie, moet die gelowige die rede, waarin God se morele wet ingegraveer is, opsoek. (bl. 134)

'Wat kan die kerk doen as morele agent in 'n sekulariserende samelewing?' vra Vorster in hoofstuk 7 (bl. 136-159). Hierop antwoord hy dat die kerk geloofwaardige, goedgefundeerde en gedefinieerde etiek as profetiese gemeenskap moet gebruik deur diep ingrypende profetiese getuienis aan die samelewing te lewer. Verder moet die kerk betrokke wees deur opinievorming. As terapeutiese gemeenskap kan elke kerk helend op die nood van die gebroke samelewing inwerk. Elke kerk kan as morele gemeenskap die voorbeeld stel van wat christelike moraliteit in die praktyk behels.

In hoofstuk 8 (bl. 160-172) word die uitgangspunt dat christelike en koninkryksetiek nie anders as hoopgewende etiek kan wees nie, bespreek:

In hierdie tussenruimte word die kerk uitgestuur om die boodskap van konkrete hoop uit te dra deur te getuig teen onreg en verdrukking en op te kom vir reg en bevryding. In sy etiek van hoop spel hy hierdie soort betrokkenheid konkreet uit. Hierdie etiek moet die kerk bevorder, en deur die betrokkenheid van die kerk in die samelewing ten gunste van mense wat in nood verkeer, moet mense hoop sien. (bl. 163)

Etiek wat nie hoop gee nie, sal nie as geloofwaardig in 'n sekulêre samelewing beskou word nie.

Wie vandag oor die rol van die kerk in 'n sekulêre samelewing nadink, sal hierdie bydrae van Vorster uiters waardevol vind. 